\title{
THE TECHNOLOGY ACCEPTANCE MODEL (TAM) ON PEPPER FARMERS IN BANGKA, INDONESIA
}

\author{
Novyandra Ilham Bahtera ${ }^{1}$ \\ Agribusiness Department, University of Bangka Belitung (UBB), Indonesia. \\ (Email: novyandra.ib@gmail.com) \\ Evahelda $^{2}$ \\ Agribusiness Department, University of Bangka Belitung (UBB), Indonesia. \\ (Email: evaheldaubb@gmail.com) \\ Eddy Jajang Jaya Atmaja ${ }^{3}$ \\ Agribusiness Department, University of Bangka Belitung (UBB), Indonesia. \\ (Email: eddyjajangjaya@gmail.com) \\ Iwan Setiawan ${ }^{4}$ \\ Agribusiness Department, University of Bangka Belitung (UBB), Indonesia. \\ (Email: binri_fam@yahoo.co.id) \\ Riko Irwanto 5 \\ Biology Department, University of Bangka Belitung (UBB), Indonesia. \\ (Email: rikoirwanto170392@gmail.com)
}

Received date: $15-08-2019$

Revised date: 23-12-2019

Accepted date: $30-12-2019$

Published date: $30-12-2019$

To cite this document: Bahtera, N. I., Evahelda., Atmaja, E. J. J., Setiawan, I., \& Irwanto, R. (2019). The Technology Acceptance Model (TAM) on Pepper Farmers in Bangka, Indonesia. Journal of Information System and Technology Management, 4(15), 48-58.

DOI: $10.35631 /$ jistm.415005

\begin{abstract}
Nowadays, the use of information technology becomes a new business model in which consumers are more open to demand their needs and take over the decision of the ideal product. However, farmers as the producers of agriculture commodities seem to be reluctant to using information technology in selling their products. The study aims to examine the effect of the perceived usefulness and perceived ease of use of information technology towards the attitude of using information technology in pepper farmers' marketing practices through the technology acceptance model. The study used face-to-face data collection and a structured questionnaire to obtain the primary data from 100 pepper farmers in Bangka Tengah and Bangka Selatan. The finding of the study shows that perceived usefulness and perceived ease of use affect significantly the attitude of using information technology among the pepper farmers in marketing practices. The results will be useful for the government and NGO to provide tools on how to disseminate the technology to potential users.
\end{abstract}

Keywords: Agribusiness Marketing, Information Technology, Pepper Farmers, Technology Acceptance Model 


\section{Introduction}

Pepper is known as having tremendous benefits. It can be used as raw material for having the potential treatment of inflammation when it is associated with curcumin (Neyrinck et al., 2013). It also can be normally used as a seasoning and spice. In Indonesia, it becomes one of the main export products. Its production has started from 1980 with 36,600 tons and it still produces until now with 82,200 tons (FAOstat, 2018). As one of the main ingredients of food, drug, and cosmetic, it is able to fulfil the consumers' need.

In the last three decades, the average of pepper production in Indonesia remains as the top producer in the world counted 67,725 ton indicating the different 8,223 ton with the second highest pepper production in the world, Vietnam (Nuryati \& Noviati, 2015; Figure 1). Despite the fact that Indonesia in average maintains the position as the top producer in the world, starting from 2004 the pepper production of Vietnam has taken over the Indonesia's pepper production counted 95,420 ton and 77,008 ton respectively (Figure 2). It leads to the condition whereby today Vietnam has become the main exporter in the world (Kementan, 2015).

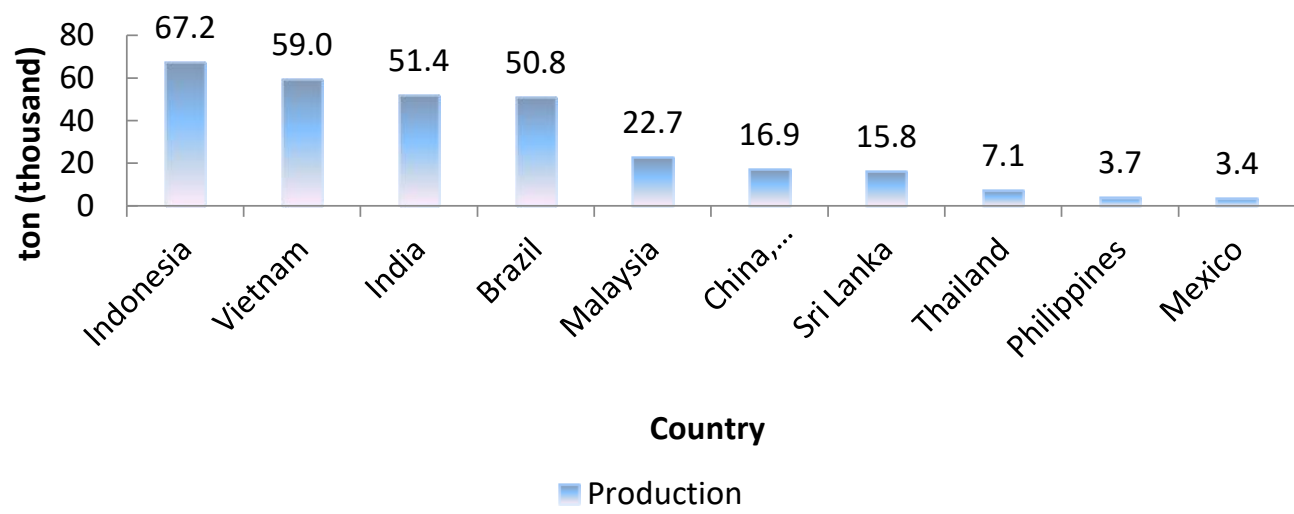

Figure 1: Pepper Production by Top 10 producers (' 000 tons), average 1980-2016 Source: FAOstat, (2018)

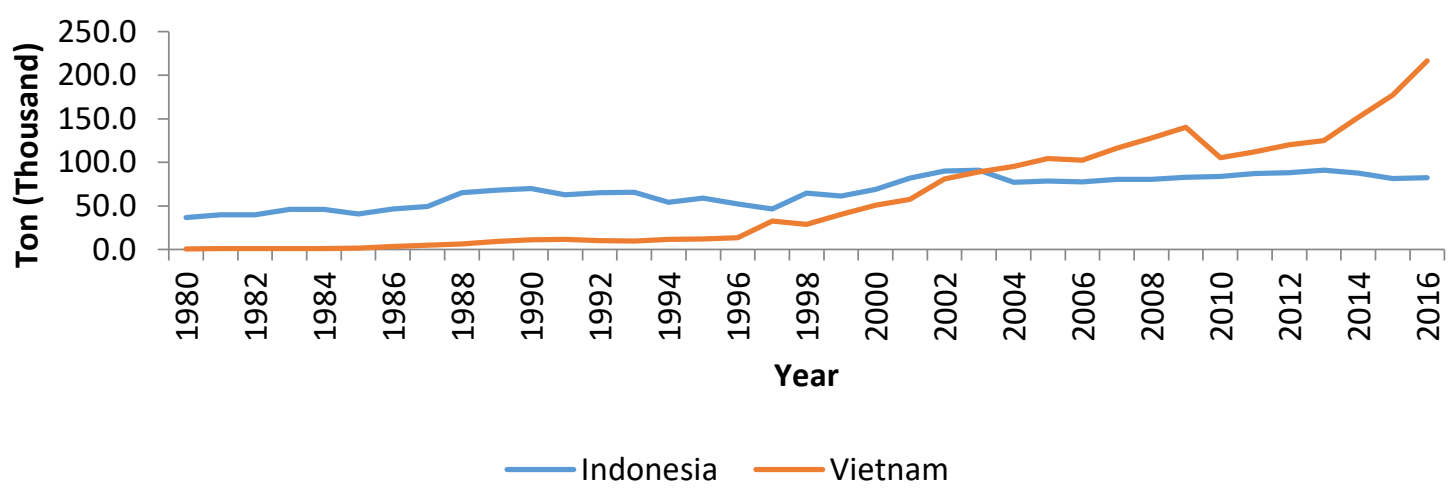

Figure 2: Pepper Production in Indonesia and Vietnam ('000 tons), 1980-2016 Source: FAOstat, (2018)

The study has decided pepper smallholder farming in Bangka Belitung as a case study which is a similar trend on the pepper production in Indonesia. As being shown in figure 2 above that the production of pepper reduces $8.9 \%$ which is gradually started from 90.2 ton in 2002 to 
82.2 ton in 2016. It makes thing worse when the price of pepper is uncertainty (Pranoto, 2010) with the high cost of production (Pranoto, 2017) due to the long supply chain system of pepper (Agustina, Yulia, \& Astuti, 2018). Lack of information about structure of pepper plantation among pepper smallholders (Putra \& Eddy, 2019) creates the obstacles of them to gain up-todate information about the current price of pepper. It indicates that policy makers require the best strategy to solve the issue. Thus, it requires to find out how the information technology as a marketing tool can be used by pepper smallholders to establish their welfare.

\section{Problem Statement}

The marketing practices among the farmers use a conventional way (Markelova et al., 2009; Gyau et al., 2014). The long supply chain keeps them difficult to survive in the industry (Poulton et al., 2005). They endeavour to improve their welfare by hoping the stable price of the agriculture commodity. In fact, they are not able to ensure the stability of the product's price since they are bonded with the middle-man. To solve, they require an alternative of selling their product by using information technology. Before doing so, it requires to understand the perception of using the technology by utilizing the model established by Davis (1986) and till now is being used by many scholars in the topic of sustainability labels on apparel products (Ma, Gam, \& Banning, 2017), of individual differences (Yuandong Yi, Zhan Wu, 2005; Stylianou \& Jackson, 2007), of gender differences (Viswanath \& Michael G, 2000), of medical education (Harmon, 2015), and of relationship quality in the hospital e-appointment system (Chen, Liu, \& Li, 2013). However, it is inadequate literature in the topic of marketing practices on the agricultural commodities. Thus, the study aims to scrutinise the influence of the perceived of usefulness and perceived ease of use of information technology towards the attitude of using information technology in pepper farmers' marketing practices through the technology acceptance model.

\section{Literature Review}

The information technology has been used in the marketing practices. It has provided a robust results in many countries. There are some researchers study about Technology Acceptance Model (TAM) which will be explained in the following passage.

\section{The Use of IT in Marketing}

The study on factors that affect the mobile customer relationship management argued that ubiquity, imminence, key drivers and message personalisation affect positively towards mobile connection as it can develop trust or known as customer relationship management. (Chan, 2012). Ma et al (2017) also did research related on the use of IT in marketing which aimed to discover the perception of consumers of sustainability labels on apparel products. They found that there were no different perception to purchase intensions of sustainability labelled apparel products between sustainability label users or non-users as long as the products' label was easy to read and useful, both types of consumer were likely to use the information on the label. However, their study was only applied in US customers which may have different results with different socio-cultural and economic background of other people in other countries or continents.

Further study, Volvenkins and Danusevics (2011) examined the use level of internet and information technology by small and medium sized enterprises (SMEs) in European Country: Latvia. They surprisingly found that the marketing activities on internet was extremely limited. It was due to lack of awareness amongst SMEs towards the website optimization as well as the other advertising activities towards the promotion of their products. In addition, big number of 
SMEs were rarely applying customer relationship management for analysing competitiveness and forecasting demand. Therefore, it affects SMEs to be less competitive.

Okibo and Michael (2014) studied about the effect of information technology on marketing of communication services. They revealed that information technology allows the customers to facilitate the endeavour of gaining information of product and implementing the communication globally. However, each person has different perception towards the use of information technology (Yi et al., 2005).

\section{The Conceptual Framework}

The technology acceptance model was initially developed and tested by Davis (1986) to identify the system characteristics' effect on user acceptance of information system on the current technology at the time when the study was conducted. Two main purposes of the TAM:

a) it provides an understanding of the user acceptance processes prior to the implementation of the information technology; and

b) it gives an information about the result's test of the user acceptance on the proposed new approach on particular information technology system.

By doing so, it is expected that the designer of the proposed IT systems will create the effective tools for the user.

Figure 3 shows the flow of the TAM. The arrow represents the causal relationships. It figures that the attitude toward using becomes the main variable on determining whether the IT system is being chosen or not.

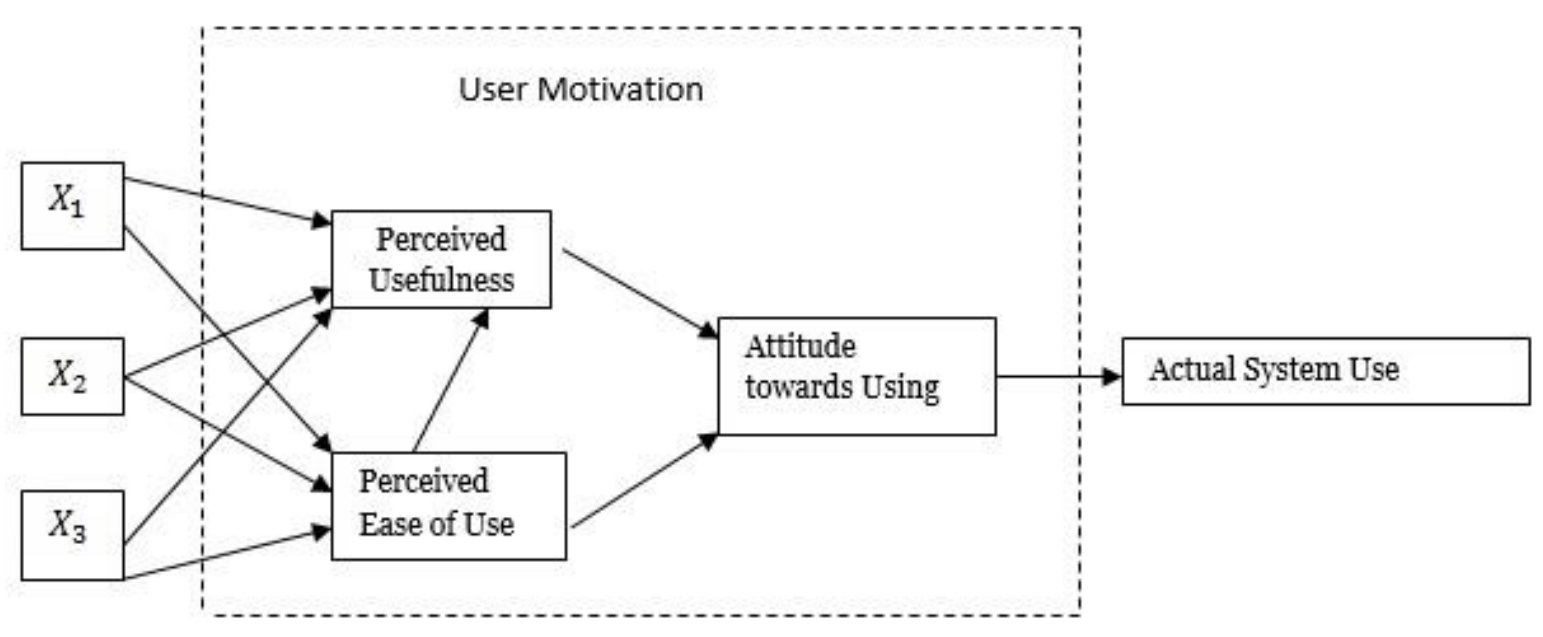

Figure 3: Technology Acceptance Model

The process of analysing the acceptance of technology using TAM provides some variables. The variables as follows (Fatmawati, 2015):

1. Perceived ease of use

It states about the perception of the users towards the ease or difficulty of information technology use. It can be identified from the following indicators: easy to learn, easy to achieve the goals, clear to operate, easy to understand, flexible information system, free from difficulty, easy to access, easy to control and overall easy to use the information technology. 


\section{Perceived usefulness}

It explains about the perception of the users towards the usefulness of the information system. The indicators are: speed up the work, increase the productivity, improve the performance, raise up the effectiveness of duty, and gain the needed information.

\section{Attitudes towards using}

It describes the attitude of the users towards the use of information technology which forms the acceptance or rejection. Thus, it shows whether the user accept or not the information technology.

\section{Actual system use}

Davis (1986) argues that actual use is defined as a person's performance of specific behaviour. It can be identified through the real condition of the particular use of information technology includes: intensity of the technology information use, frequency of the technology information use as well as the sustainable actual use of technology information.

Davis (1989) mentions that TAM is an ideal concept in explaining the behaviour of the user towards the cutting-edge information technology. They add that it is the best model in describing how users accept a particular system. Furthermore, Gefen et al (2003) states that perceived usefulness can be measured with the productivity improvement, the effective and efficient of working activity.

Study on the use of information technology using TAM has been used by many scholars worldwide (Tangke, 2004). Hambali et al (2011) studies about the acceptance of customers towards internet banking with TAM approach with some variables such as personalization, computer self-efficiency, and trust. They found that personalization, computer self-efficiency and trust have the positive impact towards perceived usefulness as customers believe that internet banking has the benefit if they have ability in operating computer.

\section{Methodology}

\section{Study Area}

Bangka Selatan and Bangka Tengah were two out of six regencies in the province of Bangka Belitung Islands, Indonesia. The area of Bangka Selatan was $3,607.08 \mathrm{~km}^{2}$ with a population of 193,583 citizens in 2015 while Bangka Tengah's area is 2,279.11 with a population of 177,218 citizens in 2015. Bangka Selatan and Bangka Tengah had 5 districts and 6 districts respectively. (Directorate General Estate of Bangka Belitung Islands Province, 2016). Purposive sampling was employed to decide the location of the study.

\section{Location of Study}

Figure 4 displayed the location of Bangka Selatan and Bangka Tengah Regency. The respondents of the study were selected from both regencies at Bangka Island to understand the technology acceptance model among pepper farmers. 


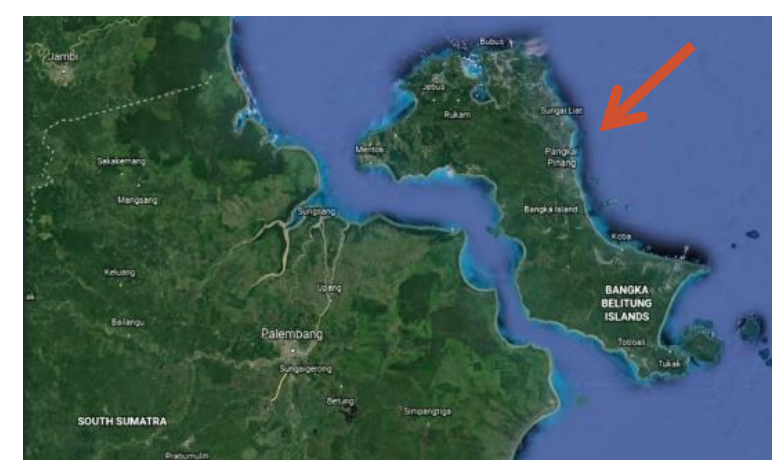

\section{Figure 4: Geographical location of Bangka Island}

\section{Research Design}

The questionnaire was designed to achieve the aim of the study. The perceived ease of use and perceived of usefulness were asked to evaluate their perception towards the using internet in daily activities. They are guided by the trained enumerators to assist the respondents in answering the five-point likert-scale of the questions ranging from 1 as the strongly disagree to 5 as strongly agree.

The pilot study was conducted on September 2018 in two regencies: Bangka Selatan and Bangka Tengah. After the data was confirmed as valid and reliable data, the data collection was further conducted from October to November 2018. The motivation for deciding this two regencies as the location of the study was that Bangka Selatan and Bangka Tengah had potential productivity of white pepper in Bangka Belitung Islands Province.

Power analysis for multiple regression was employed by following the guidance made by Wilson dan Lipsey (2001) and $\mathrm{G}^{*}$ Power software as a statistical program established by (Erdfelder \& Buchner, 1996) to determine the sampling size with alfa .05, a power of .80, and the size of moderate effect (odd ratio=1.72). Based on the mentioned assumption, the expected sampling size was 100. Hence, there were 100 farmers as the respondents in the study who were interviewed by the trained enumerators using both close and open-ended questions.

The research instrument of the study was initially written in English. Since the official language of Indonesian people was Bahasa Indonesia, it was crucial to translate the instrument into Indonesian language. The Statistical Package for Social Sciences (SPPS) version 23 was used to analyse the raw data obtained from the survey. The study used multiple regression to scrutinize the influence of the perceived of usefulness and perceived ease of use of information technology towards the attitude of using information technology in the marketing practices of pepper farmer through technology acceptance model.

\section{Result and Discussions}

Multicollinearity test showed that the perceived of used and perceived ease of use of information technology in the pepper's marketing practices correlated significantly with the attitude towards using information technology. Table 1 showed that both of the independent variables had the correlation score above 0.3 which were 0.82 (perceived of use) and 0.85 (perceived ease of use). Pallant (2016) argued that independent variables illustrated some relationship with dependent variable when the correlation score was higher than 0.3. Thus, there were relationship between perceived of use and perceived ease of use with the attitude towards using the information technology in the marketing practices. It indicated that both perceived ease of use and of usefulness can be used as the measurement to examine the attitude 
of farmers in using the information technology for their farming activity such as gaining information about current price of pepper, selling their product to the end user, acquiring the up-to-date information about the agricultural issue especially white pepper in the world and many others.

The finding was supported by the study on the perceived usefulness and perceived ease of use on the willingness to use application of government that showed both perceived had positively correlated (Hamid et al., 2016). It showed that the information technology will be used when users received the benefit and easy to use. Furthermore, the users could recommend other potential users to use the application of information technology-based (Anggraeni, 2015).

Table 1: Multicollinearity Test

\begin{tabular}{ccc}
\hline & Attitude towards using \\
\hline Pearson Correlation & Perceived of use & 0.82 \\
& Perceived ease of use & 0.85 \\
Tolerance & Perceived of use & 0.32 \\
& Perceived ease of use & 0.32 \\
VIF & Perceived of use & 3.08 \\
& Perceived ease of use & 3.08 \\
\hline
\end{tabular}

Normality test figured that the data was normally distributed. Figure 5 showed that points lied in straight diagonal line from bottom left to top right. It suggested that there was relatively no major deviation from normality. This was supported by figure 6 that showed that the residuals roughly rectangular distributed which most of the scores concentrated in the centre.

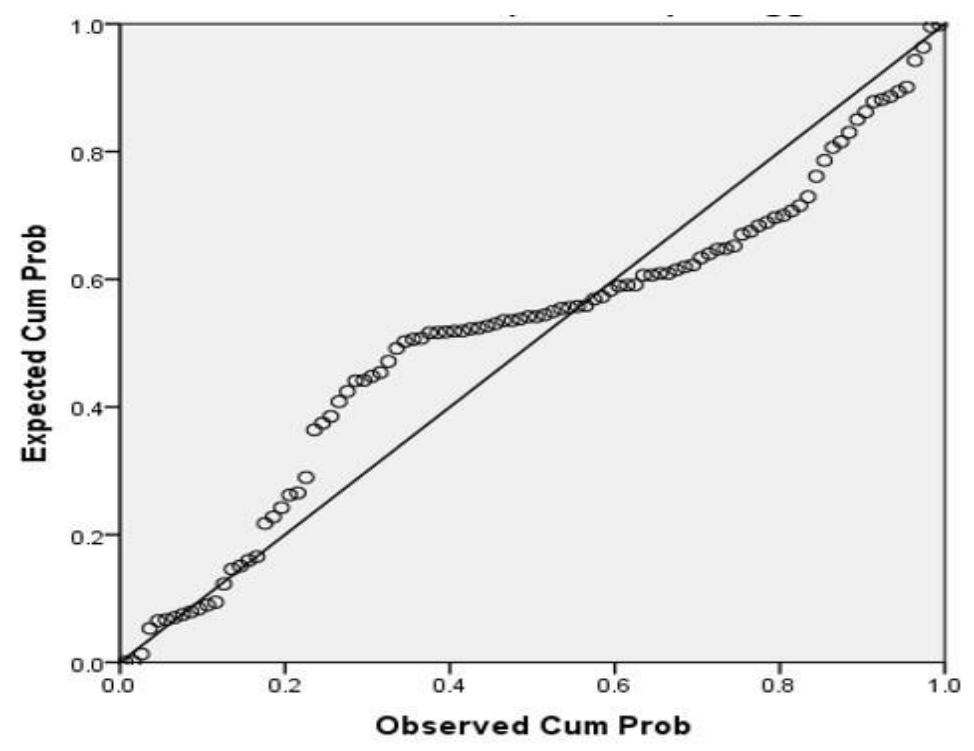

Figure 5: Normal P-P Plot of Regression Standardized Residual 


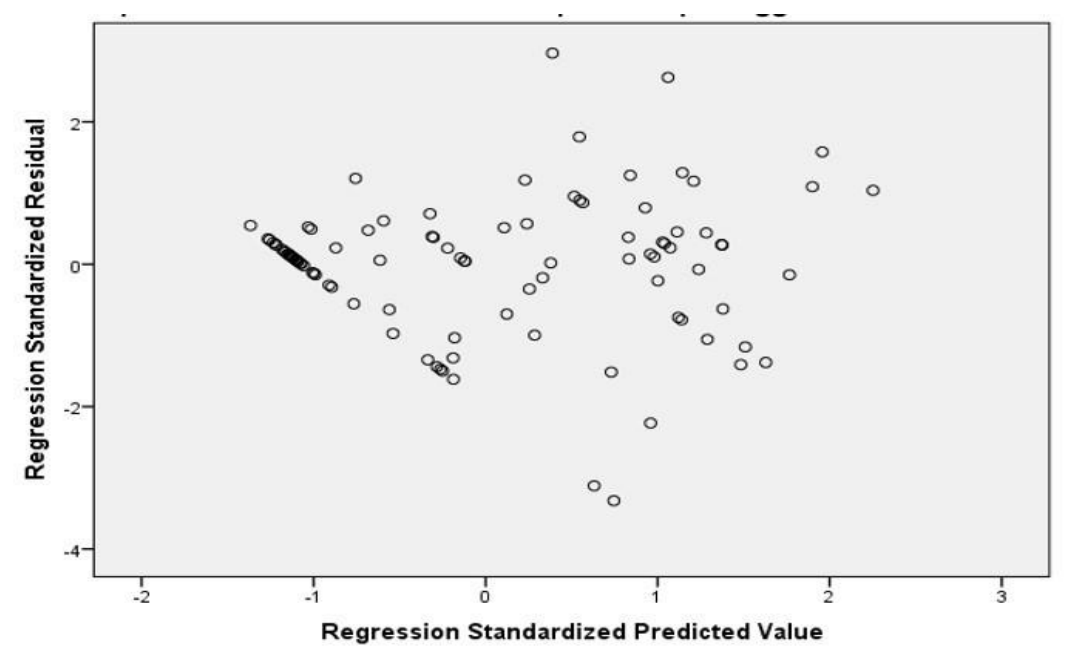

Figure 6: Scatterplot of Regression Standardized Residual

The model evaluation of the study illustrated that the R Square was 0.78 (Table 2). It meant that the perceived of use and perceived ease of use were able to explain $78 \%$ of the variance in attitude towards using the information technology in the marketing practices. In addition, the sig. value on ANOVA was 0.000. It indicated that the model had achieved the level of significance. It is obvious that the given model was significantly able to describe how pepper's farmers applied their marketing practices. It showed that the farmers had put their interest to use information technology in their marketing activities.

Table 2: Coefficient

\begin{tabular}{cccc}
\hline & Perceived of use & Perceived ease of use & Model summary \\
\hline Standardized Coefficients: Beta & 0.41 & 0.52 & \\
Sig. & 0.00 & 0.00 & 0.78 \\
R square & & & 0.78 \\
\hline
\end{tabular}

The evaluation of each independent variable was also conducted. Table 2 demonstrated the Beta value of Standardized Coefficients on the perceived ease of use (0.52) which was higher than perceived of use (0.41). It meant that perceived ease of use provided stronger unique contribution to explaining the attitude towards using the information technology on marketing practices than perceived of use.

The perceived ease of use provided some statements such as ability of farmers in using internet, ability of farmers in gaining information through internet, good quality of signal of internet, ability in using application in mobile phone or personal computer/laptop, affordable price of data package and accessibility in purchasing data package. Whereas the perceived of usefulness asked about the benefit of using internet such as gaining information about white pepper, weather forecast, business transaction, saving time, acquiring high profit, and increasing the productivity.

\section{Conclusion}

There are tremendous studies identifying the effect of information technology using technology acceptance model but lack of study specifically on the pepper as the agriculture commodity remains. The main objective of the study is to examine the effect of the perceived of usefulness and perceived ease of use of information technology towards the attitude of using information technology in pepper farmers' marketing practices through the technology acceptance model. 
The study reveals the vital input to policy maker in designing the best program to reform the marketing practices of pepper farmers.

It is suggested that the perceived of use and perceived ease of use has a positive effect on the attitude towards using the information technology in marketing practices. Most of the pepper farmers have the low level on the perceived of use and perceived of use the information technology in marketing practices. Majority of pepper farmers are lack of knowledge on the information technology. The use of information technology among pepper farmers has not been yet as the best solution to improve their welfare. The infrastructure for the use of information technology in most of the regencies in Bangka Belitung Archipelago Province is not adequate. As a result, the lack of internet connection occurs.

\section{Suggestion}

The study provides suggestions to pepper farmers in endeavouring the welfare. The farmers should be well-organized. Their participation on the empowerment program is crucial (Bahtera et al., 2016). They also should establish the solid farmer group since they remain work individually. These can be implemented as the potential characteristics of pepper farmers in Bangka Island are brave to take risks and responsive in taking opportunity (Astuti, Bahtera, \& Atmaja, 2019). In the long run, this will then result many benefits to pepper farmers. Besides, the training of the use of information technology is vital to be implemented considering the lack of ability in using the technology devices (Brown, Dennis, \& Venkatesh, 2010). Thus, it is a role of government to ensure the pepper farmers gaining a proper empowerment program. Without the involvement of policy maker, the welfare of pepper farmers would not be achieved.

\section{Acknowledgement}

We would lke to thank the Institute of Research and Community Service (Indonesian: Lembaga Penelitian dan Pengabdian kepada Masyarakat or LPPM) Bangka Belitung University for the financial support on the process of fieldwork activities through Faculty Level of Lecturer Research (Indonesian: Hibah Penelitian Dosen Tingkat Fakultas) awarded by University of Bangka Belitung with Decree Number 1812/UN50/PM/2018.

\section{References}

Agustina, F., Yulia, \& Astuti, R. P. (2018). Analysis of Supply Chain Networking on Muntok White Pepper in the Province of Bangka Belitung Islands. Russian Journal of Agricultural and Socio-Economic Sciences, 2(February), 142-147. https://doi.org/https://doi.org/10.18551/rjoas.2018-02.15 ANALYSIS

Anggraeni, R. (2015). Pengaruh Persepsi Kemudahan Penggunaan Dan Persepsi Kegunaan Terhadap Niat Untuk Menggunakan Dan Penggunaan Aktual Layanan Jejaring Sosial Berbasis Lokasi (Studi Pada Mahasiswa Fakultas Ekonomi Dan Bisnis Universitas Brawijaya Malang). Ekonomi Bisnis, 20(1), 44-52

Astuti, R. P., Bahtera, N. I., \& Atmaja, E. J. J. (2019). Entrepreneurial Characteristics and Behaviors of Muntok White Pepper Farmers. Society, 7(2), 101-115. https://doi.org/10.33019/society.v7i2.116

Bahtera, N. I., Arshad, F. M., Sidique, S. F., Djama, M., Abu-samah, A., \& Studies, F. P. (2016). The determinants of participation in empowerment programs in jambi province, indonesia. Asia Pacific Journal of Advanced Business and Social Studies2, 2(2), 534550.

Brown, S. A., Dennis, A. R., \& Venkatesh, V. (2010). Predicting Collaboration Technology Use: Integrating Technology Adoption and Collaboration Research. Journal of 
Management Information Systems, 27(2), 9-54. https://doi.org/10.2753/MIS07421222270201

Chan, T. Y. T. (2012). Mobile customer relationship management: Factors affecting consumer mobile technology adoption within the hotel industry. Studies by Undergraduate Researchers at Guelph, 5(2), 44-50. Retrieved from https://search.proquest.com/docview/1412258403/fulltextPDF/DB87CF4471884332P $\mathrm{Q} / 2$ ? accountid=38628

Chen, S., Liu, S., \& Li, S. (2013). Understanding the Mediating Effects of Relationship Quality on Technology Acceptance: An Empirical Study of E-Appointment System. Journal of Medical Systems, (40). https://doi.org/10.1007/s10916-013-9981-0

Davis, F. D. (1986). A technology acceptance model for empirically testing new end-user information systems: Theory and results. Management, Ph.D.(April), 291. https://doi.org/oclc/56932490

Directorate General Estate of Bangka Belitung Islands Province. 2016. A Report.

Erdfelder, E., \& Buchner, A. (1996). GPOWER : A general power analysis program, 28(I), 111

Food and Agriculture Organization of the United Nations. (2018). FAOSTAT statistical database. [Rome] :FAO

Gyau, A., Franzel, S., Chiatoh, M., Nimino, G., \& Owusu, K. (2014). Collective action to improve market access for smallholder producers of agroforestry products: Key lessons learned with insights from Cameroon's experience. Current Opinion in Environmental Sustainability, 6(1), 68-72. https://doi.org/10.1016/j.cosust.2013.10.017

Hamid, A. A., Razak, F. Z. A., Bakar, A. A., \& Abdullah, W. S. W. (2016). The Effects of Perceived Usefulness and Perceived Ease of Use on Continuance Intention to Use EGovernment. Procedia Economics and Finance, 35(October 2015), 644-649. https://doi.org/10.1016/s2212-5671(16)00079-4

Harmon, D. J. (2015). User Acceptance of a Novel Anatomical Sciences Mobile App for Medical Education-An Extension of the Technology Acceptance Model. The Ohio State University

Kementan. (2015). Komoditas Pertanian Subsektor Tanaman Pangan Padi, 103

Ma, Y. J., Gam, H. J., \& Banning, J. (2017). Perceived ease of use and usefulness of sustainability labels on apparel products: application of the technology acceptance model. Fashion and Textiles, 4(1), 1-21. https://doi.org/10.1186/s40691-017-0093-1

Markelova, H., Meinzen-Dick, R., Hellin, J., \& Dohrn, S. (2009). Collective action for smallholder market access. Food Policy, 34(1), 1-7. https://doi.org/https://doi.org/10.1016/j.foodpol.2008.10.001

Neyrinck, A. M., Alligier, M., Memvanga, P. B., Névraumont, E., Larondelle, Y., Préat, V., Delzenne, N. M. (2013). Curcuma longa Extract Associated with White Pepper Lessens High Fat Diet-Induced Inflammation in Subcutaneous Adipose Tissue. Plos One, 8(11), 1-11. https://doi.org/10.1371/journal.pone.0081252

Nuryati, L., \& Noviati. (2015). Outlook Lada, 88. Retrieved from http://epublikasi.setjen.pertanian.go.id/epublikasi/outlook/2015/Perkebunan/Outlook Lada 2015/files/assets/common/downloads/Outlook Lada 2015.pdf

Okibo, W., \& Michael, L. (2014). Effect of Information Technology on Marketing of Communication Services: a Case Study of Bharti Airtel Kenya Ltd. International Journal of Economics, Commerce and Management United Kingdom, II(9), 1-17. Retrieved from http://ijecm.co.uk/

Pallant, J. (2016). Julie Pallant-SPSS Survival Manual_A Step by Step Guide to Data Analysis Using IBM SPSS-Open University Press (2016) (Sixth). New York: McGraw-Hill Education 
Pranoto, Y. S. (2010). Faktor yang Mempengaruhi Keputusan Petani Terhadap Hasil Panen Lada Putih di Kecamatan Simpang Teritip Kabupaten Bangka Barat. Journal of Agribusiness and Rural Development Research, 2(1), 69-74. https://doi.org/10.18196/agr.2127

Pranoto, Y. S. (2017). Pengaruh Input terhadap Produksi Usahatani Lada Putih (Muntok White Pepper) di Desa Kundi Kecamatan Simpang Teritip Kabupaten Bangka Barat. Journal of Social and Agricultural Economics, 9(3), 1-7. Retrieved from https://jurnal.unej.ac.id/index.php/JSEP/article/view/5812

Putra, G. B., \& Eddy, J. J. A. (2019). Digitalisasi Data Muntok White Pepper untuk Mendukung Produktivitas dan Pemasaran Secara Global Berbasis Internet dan Android. Serambi Engineering, IV(1), 376-382. Retrieved from https://ojs.serambimekkah.ac.id/index.php/jse/article/view/847

Stylianou, A. C., \& Jackson, P. J. (2007). A Comparative Examination of Individual Differences and Beliefs on Technology Usage: Gauging the Role of It. A Comparative Examination of Individual Differences and Beliefs on Technology Usage: Gauging the Role of It., 47(4), 11-18. Retrieved from http://search.ebscohost.com/login.aspx?direct=true $\& d b=i i h \& A N=26000732 \&$ site $=e h$ ost-live

Viswanath, V., \& Michael G, M. (2000). Why Don't Men Ever Stop to Ask for Directions? Gender, Social Influence, and Their Role in Technology Acceptance and Usage Behavior. MIS Quarterly, 24(1), 115-139. Retrieved from http://search.ebscohost.com/login.aspx?direct=true \&db=iih\&AN=3205163\&site=ehos t-live

Volvenkins, S., \& Danusevics, M. (2011). the Use of Internet and It By Small and MediumSized, 4(09), 443-452

Wilson, D. B., \& Lipsey, M. W. (2001). The role of method in treatment effectiveness research: Evidence from meta-analysis. Psychological Methods, 6(4), 413

Yi, Y., Wu, Z., \& Tung, L. L. (2005). How Individual Differences Influence Technology Usage Behavior? Toward an Integrated Framework. Journal of Computer Information Systems, 46(2), 52-63. Retrieved from http://search.ebscohost.com/login.aspx?direct=true \&db=iih\&AN=19609350\&site=eh ost-live 